\title{
ANALISIS TINGKAT KUALITAS PELAYANAN JASA MENGGUNAKAN METODE SERVICE QUALITY (SERVQUAL) FUZZY DI INSTALASI RADIOLOGI RUMAH SAKIT UMUM DAERAH (RSUD) PANEMBAHAN SENOPATI BANTUL
}

\author{
Dwi Suharyanta, Qurrota A'yunin \\ Prodi Kesehatan Masyarakat, STIKES Surya Global Yogyakarta
}

\begin{abstract}
Background: To provide a quality service to the customer (patient) needs to be a measure of the quality of existing services, covering five dimensions, namely reliability, responsiveness, assurance, empathy, and tangibles in order to create a patient satisfaction. To determine the level of quality, can be measured from the expectations and perceptions of customers (patients).

Method: Using the Service Quality (Servqual) method integrated in the Fuzzy. Fuzzy Servqual method is the instrument to measure the service quality between costumer's (as patient) expectation and costumer's (as patient) perception. Fuzzy set theory to accomode subjectivity and ambiguity on quality service judgement.

Conclusion: Using the method acquired Fuzzy Sevqual five attributes / criteria that are a priority for improved quality of services because it has a value of Servqual (Gap) weighted the most. Attributes that are Facilities provided incomplete and inadequate with a value of -1.417 servqual, for the second order The equipment used not using the latest technology (advanced) of -1.313 , which is third on The officer has not been attentive to treat patients with a value of 1.250 servqual, for the fourth and final fifth Handling of complaints and Non-radiology is not convenient of -1.146 . Where three of the above criteria is of dimension Tangibles, so the main priority to be repaired and improved quality of care is of the dimension Tangibles with a total score of -1.161 . The quality of service in the Installation of Radiology of the overall gap calculation results show a negative gap value is -0.961 , meaning what is expected according to what the customer has not obtained the customer at the Hospital Radiology Installation Panembahan Senopati Bantul.
\end{abstract}

Keywords: Installing Panembahan Senopati Bantul District Hospital Radiology, Fuzzy, Servqual Gap, Fuzzy-Servqual, Quality service.

\section{PENDAHULUAN}

Rumah Sakit Umum Daerah (RSUD) Panembahan Senopati merupakan salah satu instansi daerah yang bergerak pada pelayanan kesehatan terutama di daerah Bantul yang telah memperoleh sertifikasi Akreditasi tahun 2010. Dalam menjalankan usaha pelayanan kesehatan, RSUD Panembahan Senopati berusaha menempatkan kualitas pelayanan sebagai suatu hal yang penting dan utama. Hal ini dapat dilihat dari visi RSUD Panembahan Senopati yaitu "Tewujudnya rumah sakit yang unggul dan menjadi pilihan utama masyarakat Bantul dan sekitarnya".

Dalam rangka untuk meningkatkan pelayanan kesehatan perlu dijaga kualitas pelayanan salah satunya dengan melakukan survei kepuasan pelanggan. Dari hasil survei kepuasan pelanggan yang dilakukan pada bulan September 2011 terhadap 300 pengunjung, untuk mengetahui kepuasan pelanggan dilihat dari kesenjangan harapan dan persepsi terhadap mutu pelayanan, didapatkan hasil 
skor Indeks Kepuasan Masyarakat (IKM) untuk responden rawat jalan sebesar $2.956(73,9 \%)$ dan rawat inap di dapatkan skor IKM sebesar 3,107 (77,6\%). Untuk Instalasi Radiologi, skor IKM yang di peroleh sebesar 2,996 (74,91\%).

Berdasarkan hasil observasi melalui kotak saran, sms center pada bulan Januari hingga Agustus 2011 dan wawancara terhadap pasien, serta penelitian di Instalasi Radiologi yang dilakukan peneliti dikaitkan dengan dimensi mutu Parasuraman, Zeithaml, dan Berry (1985) yang membagi dimensi kualitas pelayanan menjadi lima kelompok (Yamit, 2010), diketahui bahwa masih banyak keluhan pasien diantaranya:

a. Reliability (kehandalan), yaitu kemampuan memberikan pelayanan yang dijanjikan dengan segera, akurat dan memuaskan. Tetapi menurut pasien, pelayanan yang diberikan petugas masih lama karena memang proses pemberian pelayanan dari mulai pendaftaran, pemeriksaan, sampai menerima hasil foto menurut SPM (Standar Pelayanan Minimal) \pm 2 jam sedangkan pemahaman pasien kurang dan memang selesainya pemberian layanan lebih dari 2 jam sehingga menyebabkan pasien tidak puas.

b. Tangibles (bukti langsung) meliputi fasilitas fisik, perlengkapan, pegawai dan sarana komunikasi. Pada kenyataannya, alat yang tersedia belum mencukupi kebutuhan , apabila pasien banyak maka akan membuat antrian panjang dan pasien harus menunggu lama dan kadang sampai mengulang hingga beberapa kali yang menyebabkan pasien merasa tidak puas.

c. Responsiveness (daya tanggap), yaitu keinginan para staf untuk membantu para pelanggan dan memberikan pelayanan dengan tanggap. Kenyataannya, petugas kurang teliti dalam hal pemberian layanan kepada pasien dimana dalam SPM angka kerusakan film tidak boleh lebih dari $2 \%$ tapi kenyataannya kerusakan film masih diatas $2 \%$, terbukti dengan keluhan pasien harus dilakukan tiga kali foto thoraks karena hasil foto tidak jelas sehingga membuat pasien rela mengeluarkan uang lebih dan menunggu lebih lama.

d. Assurance (jaminan) yang mencakup pengetahuan, kemampuan, kesopanan, dan sifat dapat dipercaya yang dimiliki staf bebas dari bahaya, risiko atau keragu-raguan. Pada kenyataannya, belum seluruh petugas mematuhi standar yang telah ditentukan seperti pemakaian Alat Perlindungan Diri (APD) yang dapat membahayakan mereka dan pasien.

Penilaian tentang kualitas pelayanan dapat berbeda-beda bagi setiap orang yang mengakibatkan terjadi subyektifitas dari penilai. Hal yang membuat pengukuran terhadap kualitas pelayanan sulit untuk diukur dikarenakan tidak ada ukuran yang pas yang dapat menyamakan persepsi orang terhadap kualitas pelayanan sehingga pengukuran terhadap derajat kepuasan pelayanan terkadang kurang akurat, ambigu, tidak presisi dan cenderung subyektif. Salah satu metode pendekatan yang dipakai untuk mengukur kualitas pelayanan adalah konsep Fuzzy - servqual.

Konsep Fuzzy - servqual adalah sebuah teori pengukuran yang mengakomodir bahasa linguistik dengan bahasa numerik (angka/statistik). Faktor ketidakpresisian telah diakomodasi dalam sebuah penilaian variabel linguistik yang mengadaptasi ketidakpresisian data, ambiguitas dan subjektifitas, yang tidak dapat dilakukan dengan model servqual biasa. (Kusumadewi, 2010).

Metode fuzzy - servqual digunakan untuk menyelesaikan permasalahan di

RSUD Panembahan Senopati tentang penilaian kualitas pelayanan terutama di Instalasi Radiologi sehingga tercipta kualitas pelayanan yang lebih baik di masa yang akan datang. 
2. METODE

Penelitian ini merupakan penelitian deskriptif yaitu metode penelitian yang dilakukan dengan tujuan memberikan gambaran atau deskripsi tentang suatu keadaan secara obyektif, dengan pendekatan kuantitatif karena data penelitian berupa angka-angka dan analisa menggunakan statistik (Sugiyono, 2009). Dan menggunakan rancangan cross sectional dimana pengumpulan data untuk variabel terikat maupun variabel bebas dilakukan dalam waktu yang bersamaan (Notoatmodjo, 2010).

Populasi dalam penelitian ini adalah semua pasien yang berkunjung ke Instalasi Radiologi yang berasal dari poliklinik rawat jalan, rawat inap, IGD, ICU, dan dokter praktek di luar rumah sakit yang mendapat pelayanan radiologi. Jumlah populasi pada penelitian ini selama bulan Januari sampai dengan Desember 2011 sebanyak 25.555 pasien. Dengan rata-rata pasien per bulan sebesar 2.130 pasien. Sampel dalam penelitian ini adalah pasien atau keluarga pasien (mewakili pasien) yang berumur antara 17 - 75 tahun dan pernah mendapatkan pelayanan radiologi yang berkaitan dengan pelayanan radiodiagnostik minimal satu kali pelayanan di Instalasi Radiologi RSUD Panembahan Senopati Bantul.

Data yang digunakan dalam penelitian ini adalah data primer, yaitu adalah sumber data yang langsung memberikan data kepada pengumpul data (Sugiyono,2009). Dalam pengumpulan data primer, peneliti menggunakan tiga teknik pengumpulan data, yaitu : wawancara, pengamatan / observasi dan kuesioner (angket) dan pengumpulan data skunder dengan cara penelusuran dokumentasi, yaitu memperoleh data melalui buku-buku literatur baik menggunakan catatan yang berhubungan dengan permasalahan, maupun menghimpun data-data yang dikumpulkan pihak lain sebelumnya (orang lain).

Instrumen penelitian ini berupa kuesioner yang digunakan untuk mengetahui karakteristik responden meliputi nama, usia, alamat, jenis kelamin, pendidikan, pekerjaan, dan asal pasien. Selain menggunakan kuesioner sebagai instrument penelitian, dalam penelitian ini juga di dukung wawancara mendalam.

Analisis data dilakukan dengan tahap awal mengintegrasikan servqual dengan fuzzy, dimana penggunaan metode ini pada kemampuannya untuk bisa menangkap dan subjektifitas yang terjadi pada pengumpulan data melalui kuesioner, mengingat adanya perbedaan penilaian seseorang terhadap suatu bahasa penelitian, selain itu juga kemampuannya untuk dapat mengetahui variabel-variabel yang harus diperhatikan untuk ditingkatkan berdasarkan nilai potensial kepuasaan konsumen dalam perbaikan pelayanan kepada pelanggan lebih terfokus sehingga kepuasan pelanggan dapat tercapai dengan baik. Pengintegrasian Fuzzy-Servqual yang dilakukan meliputi pembentukan membership function dengan Triangular Fuzzy Number untuk pengukuran persepsi dan ekspektasi pelanggan, perhitungan nilai kesenjangan kualitas layanan, perhitungan bobot, perhitungan nilai servqual terbobot dan penilaian tingkat kepentingan suatu kriteria. Tahap kedua dilakukan proses fuzzyfikasi berikutnya dengan pembentukan Triangular fuzzy Number nilai persepsi dan ekspektasi pelanggan. Tahap ketiga adalah melakukan defuzzifikasi untuk mendapatkan suatu nilai tunggal yang representatif dengan menggunakan Arithmatic Mean yang diformulasikan sebagai berikut: $\boldsymbol{\mu} \boldsymbol{A} \cap \boldsymbol{B}=(\boldsymbol{\mu A} \boldsymbol{x}+$ 
$\boldsymbol{\mu} \boldsymbol{B}[\boldsymbol{y}]) / \mathbf{2}$. Tahap terakhir yang dilakukan pada penelitian ini adalah penarikan kesimpulan.

\section{HASIL PENELITIAN DAN PEMBAHASAN}

\section{Mengintegrasikan Fuzzy - Servqual}

Penentuan fuzzy set dilakukan untuk menentukan skor yang harus diberikan oleh responden untuk setiap kriteria yang diajukan dalam kuesioner. Cara penentuannya seperti terlihat pada gambar 4.1 sebagai berikut:

$\mu \mathrm{m}(\mathrm{X})$

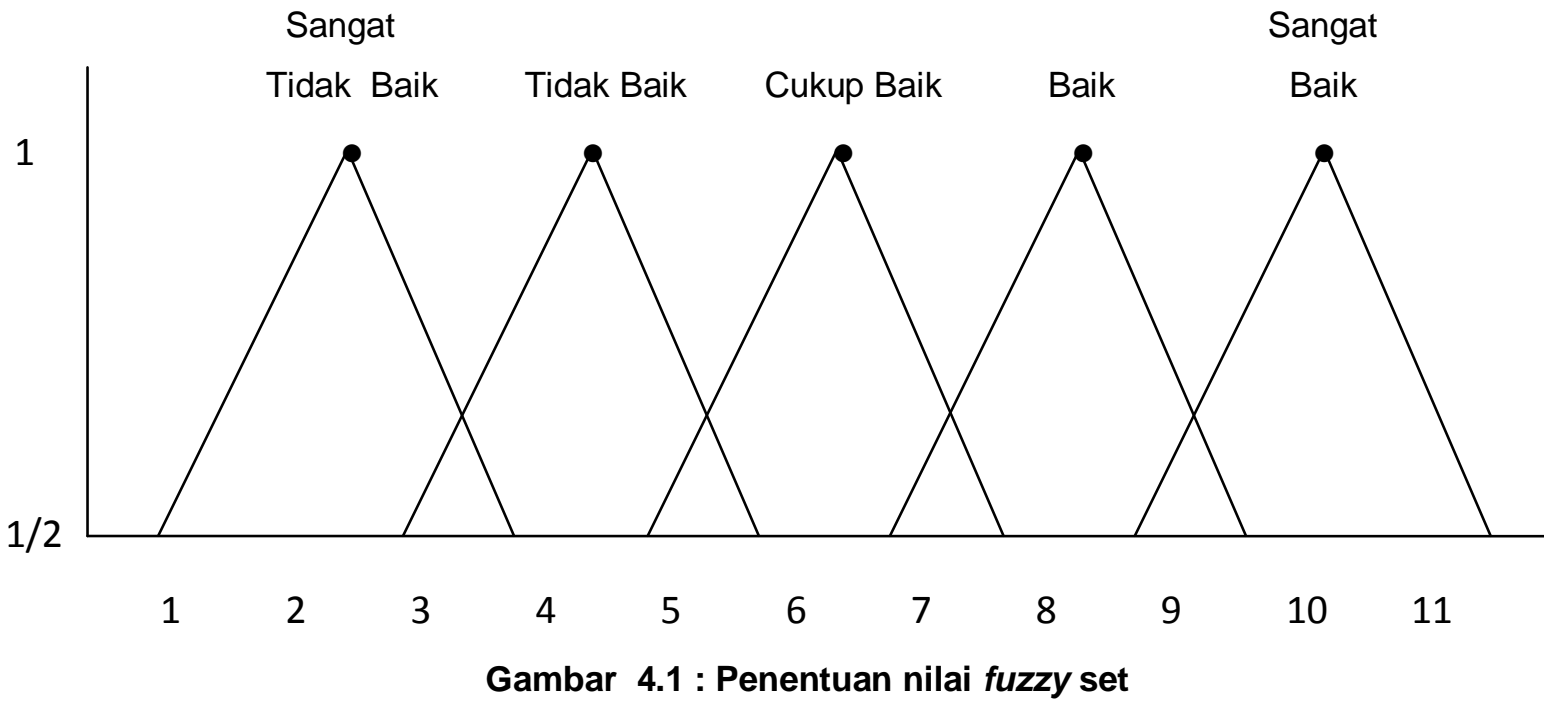

Dengan demikian, nilai yang digunakan dalam penentuan bobot (skor) yang kita gunakan untuk mengetahui tingkat kualitas pelayanan dari perhitungan nilai fuzzyfikasi adalah sebagai berikut:

a. Katagori 1 = Sangat Tidak Baik dengan skor 1,2,3,4

(meliputi jawaban kuesioner Persepsi/Harapan yaitu Sangat Tidak Setuju/ Sangat Tidak Diharapkan).

b. Katagori 2 = Tidak Baik dengan skor 3,4,5,6

(meliputi jawaban kuesioner Persepsi/Harapan yaitu Tidak Setuju/Tidak Diharapkan).

c. Katagori 3 = Cukup Baik dengan skor 5,6,7,8

(meliputi jawaban kuesioner Persepsi/Harapan yaitu Setuju/Cukup Diharapkan).

d. Katagori $4=$ Baik dengan skor 7,8,9,10

(meliputi jawaban kuesioner Persepsi/Harapan yaitu Setuju/Cukup Diharapkan).

e. Katagori 5 = Sangat Baik dengan skor 9,10,11,12

(meliputi jawaban kuesioner Persepsi/Harapan yaitu Sangat Setuju/Sangat Diharapkan)

\section{Perhitungan Nilai Fuzzyfikasi Persepsi Pelanggan}


Dalam menghitung nilai fuzzyfikasi kuesioner persepsi pelanggan dengan menggunakan software Ms. Excel, dimana nilai fuzzyfikasi merupakan nilai rata-rata dari nilai c, a, b. Perangkingan dilakukan dari nilai tertinggi ke nilai yang terendah. Sedangkan hasil perhitungan nilai fuzzyfikasi dapat dilihat pada tabel 4.9 dibawah ini:

Tabel 4.9 Hasil Rekapitulasi Data Persepsi Pelanggan sesuai dengan Tingkat Kepentingan

\begin{tabular}{|c|c|c|c|c|c|c|}
\hline No & Kriteria & $\begin{array}{c}\text { Sangat } \\
\text { Tidak } \\
\text { Baik } \\
\text { (1) }\end{array}$ & $\begin{array}{c}\text { Tidak } \\
\text { Baik } \\
(2)\end{array}$ & $\begin{array}{c}\text { Cukup } \\
\text { Baik } \\
(3)\end{array}$ & $\begin{array}{c}\text { Baik } \\
(4)\end{array}$ & $\begin{array}{c}\text { Sangat } \\
\text { Baik } \\
\text { (5) }\end{array}$ \\
\hline 1. & $\begin{array}{l}\text { Petugas memberikan } \\
\text { pelayanan secara tepat }\end{array}$ & 1 & 0 & 16 & 51 & 28 \\
\hline 2. & $\begin{array}{lr}\begin{array}{l}\text { Kesesuaian } \\
\text { dengan } \\
\text { ditawarkan }\end{array} & \text { janji } \\
\end{array}$ & 0 & 1 & 21 & 54 & 20 \\
\hline 3. & $\begin{array}{l}\text { Petugas memberikan } \\
\text { pelayanan sesuai dengan } \\
\text { waktu yang dijanikan }\end{array}$ & 0 & 3 & 13 & 49 & 30 \\
\hline 4. & $\begin{array}{l}\text { Petugas tidak harus } \\
\text { membuat catatan medis }\end{array}$ & 1 & 3 & 13 & 49 & 30 \\
\hline 5. & $\begin{array}{l}\text { Petugas Radiologi tidak } \\
\text { sigap dalam menangani } \\
\text { pasien }\end{array}$ & 0 & 2 & 11 & 59 & 24 \\
\hline 6. & $\begin{array}{l}\text { Pelayanan yang segera / } \\
\text { cepat bagi pasien }\end{array}$ & 0 & 3 & 20 & 42 & 31 \\
\hline 7. & $\begin{array}{l}\text { Kesediaan petugas untuk } \\
\text { membantu pasien }\end{array}$ & 0 & 0 & 17 & 50 & 29 \\
\hline 8. & $\begin{array}{l}\text { Petugas } \text { memberikan } \\
\text { informasi yang jelas } \\
\text { kepada pasien seputar } \\
\text { pelayanan Radiologi }\end{array}$ & 0 & 1 & 19 & 45 & 31 \\
\hline 9. & $\begin{array}{ll}\text { Penanganan } & \text { terhadap } \\
\text { keluhan pasien } & \\
\end{array}$ & 0 & 2 & 23 & 45 & 26 \\
\hline 10. & $\begin{array}{l}\text { Petugas mampu membuat } \\
\text { pasien merasa aman saat } \\
\text { diberikan pelayanan }\end{array}$ & 0 & 1 & 16 & 46 & 33 \\
\hline 11. & $\begin{array}{lr}\text { Petugas Radiologi tidak } \\
\text { terampil } & \text { dalam } \\
\text { memberikan pelayanan }\end{array}$ & 1 & 1 & 12 & 52 & 30 \\
\hline 12. & $\begin{array}{l}\text { Petugas mampu } \\
\text { menumbuhkan rasa } \\
\text { percaya kepada pasien }\end{array}$ & 0 & 2 & 18 & 50 & 26 \\
\hline 13. & $\begin{array}{l}\text { Petugas tidak mampu } \\
\text { menjawab } \\
\text { pasien }\end{array}$ & 1 & 2 & 6 & 59 & 28 \\
\hline
\end{tabular}




\begin{tabular}{|c|c|c|c|c|c|c|}
\hline 14. & $\begin{array}{l}\text { Kemudahan untuk } \\
\text { menghubungi Rumah Sakit } \\
\text { (Radiologi) }\end{array}$ & 0 & 0 & 18 & 49 & 29 \\
\hline 15. & $\begin{array}{lr}\begin{array}{l}\text { Petugas } \\
\text { memahami }\end{array} & \text { mampu } \\
\text { pasien } & \end{array}$ & 0 & 4 & 20 & 47 & 25 \\
\hline 16. & $\begin{array}{l}\text { Petugas memperlakukan } \\
\text { pasien penuh perhatian }\end{array}$ & 0 & 5 & 19 & 46 & 26 \\
\hline 17. & $\begin{array}{l}\text { Petugas Radiologi mampu } \\
\text { berkomunikasi } \\
\text { dengan pasien }\end{array}$ & 0 & 1 & 17 & 53 & 25 \\
\hline 18. & $\begin{array}{l}\text { Petugas yang raamah dan } \\
\text { sopan dalam melayani } \\
\text { pasien }\end{array}$ & 0 & 1 & 13 & 52 & 30 \\
\hline 19. & $\begin{array}{l}\text { Ruangan Radiologi (ruang } \\
\text { pemeriksaan, ruang } \\
\text { tunggu) yang bersih, rapi, } \\
\text { dan nyaman }\end{array}$ & 0 & 1 & 21 & 46 & 28 \\
\hline 20. & $\begin{array}{l}\text { Peralatan yang digunakan } \\
\text { menggunakan teknologi } \\
\text { terbaru (mutakhir) }\end{array}$ & 0 & 4 & 33 & 39 & 20 \\
\hline 21. & $\begin{array}{l}\text { Penampilan petugas } \\
\text { Radiologi yang rapi dan } \\
\text { sopan }\end{array}$ & 0 & 0 & 15 & 57 & 24 \\
\hline 22 . & $\begin{array}{l}\text { Fasilitas yang tersedia } \\
\text { lengkap dan memadai }\end{array}$ & 1 & 2 & 21 & 51 & 21 \\
\hline
\end{tabular}

Sumber: Data Primer Tahun 2012

Perhitungan nilai fuzzyfikasi data kuesioner dilakukan dengan rumus berikut:

Batas bawah (c) $\quad=\frac{b_{i 1}{ }^{*} n_{1}+b_{i 1} * n_{2}+b_{i 2}{ }^{*} n_{3}+\ldots \ldots . .+b_{i(k-1)} * n_{k}}{n_{1}+n_{2}+n_{3}+\ldots \ldots . . n_{k}}$

Nilai tengah (a) $=\frac{b_{i 1}{ }^{*} n_{1}+b_{i 2}{ }^{*} n_{2}+b_{i 3} * n_{3}+\ldots \ldots .+b_{i k} * n_{k}}{n_{1}+n_{2}+n_{3}+\ldots \ldots . . n_{k}}$

Batas atas (b)

$$
=\frac{\left.b_{i 2} * n_{1}+b_{i 3} * n_{2}+\ldots \ldots+b_{i \mathfrak{k}} * n_{i(k-1)}+b_{i k} * n_{k}\right)}{n_{1}+n_{2}+n_{3}+\ldots \ldots . . n_{(k-1)}+n_{j k}}
$$

Keterangan:

$b_{i}=$ rata-rata nilai fuzzy set per tingkat kepentingan

$\mathrm{n}=$ jumlah responden per tingkat kepentingan

Dengan rumus di atas, maka nilai $a, b$, dan c adalah:

Batas bawah $(\mathrm{c})=\left(1^{*} 1\right)+\left(3^{*} 0\right)+\left(5^{\star} 16\right)+\left(7^{*} 51\right)+\left(9^{\star} 28\right)$ 


$$
\begin{aligned}
& 1+0+16+51+28 \\
= & \frac{1+0+80+357+252}{96} \\
= & \frac{690}{96}=7,188
\end{aligned}
$$

Nilai Tengah $(\mathrm{a})=\left(2,5^{\star} 1\right)+\left(4,5^{\star} 0\right)+\left(6,5^{\star} 16\right)+\left(8,5^{\star} 51\right)+\left(10,5^{\star} 28\right)$

$$
\begin{aligned}
& =\frac{2,5+0+104+433,5+294}{96} \\
& =\frac{834}{96}=8,688
\end{aligned}
$$

$$
\begin{aligned}
\text { Batas Bawah }(\mathrm{b}) & =\frac{\left(4^{*} 1\right)+\left(6^{*} 0\right)+\left(8^{*} 16\right)+\left(10^{*} 51\right)+\left(12^{*} 28\right)}{1+0+16+51+28} \\
& =\frac{4+0+128+510+336}{96} \\
& =\frac{978}{96}=10,188
\end{aligned}
$$

Setelah masing-masing kriteria didapatkan selisihnya, maka pada tahap selanjutnya adalah melakukan defuzzyfikasi untuk mendapatkan suatu nilai tunggal yang representatif dengan menggunakan Arithmatic Mean yang diformulasikan sebagai berikut : $\mu A \cap B=(\mu A x+\mu B[y]) / 2$.

Maka contoh perhitungan defuzzyfikasinya adalah sebagai berikut:

$$
\begin{aligned}
\mu A \cap B & =\frac{8,688+10,188}{2} \\
& =9,438
\end{aligned}
$$

Sedangkan hasil perhitungan nilai fuzzyfikasi perangkingan dilakukan dari nilai tertinggi ke nilai terendah dapat dilihat pada tabel 4.10:

Tabel 4.10 Nilai defuzzyfikasi Persepsi Pelanggan

\begin{tabular}{ccccccc}
\hline \multirow{2}{*}{ No } & \multicolumn{2}{c}{ Kriteria } & \multicolumn{3}{c}{ TFN } & \multicolumn{2}{c}{$\begin{array}{c}\text { Defuzzy } \\
\text {-fikasi }\end{array}$} & Rank \\
\cline { 3 - 5 } & & C & a & b & \\
\hline 1 & $\begin{array}{l}\text { Petugas memberikan } \\
\text { pelayanan }\end{array}$ & 7.188 & 8.688 & 10.188 & 9.438 & 8 \\
\hline
\end{tabular}




\begin{tabular}{|c|c|c|c|c|c|c|}
\hline & tepat & & & & & \\
\hline 2 & $\begin{array}{l}\text { Kesesuaian } \\
\text { pelayanan dengan } \\
\text { janji yang ditawarkan }\end{array}$ & 6.938 & 8.438 & 9.938 & 9.188 & 20 \\
\hline 3 & $\begin{array}{l}\text { Petugas memberikan } \\
\text { pelayanan sesuai } \\
\text { dengan waktu yang } \\
\text { dijanikan }\end{array}$ & 7.156 & 8.641 & 10.125 & 9.383 & 12 \\
\hline 4 & $\begin{array}{l}\text { Petugas tidak harus } \\
\text { membuat catatan } \\
\text { medis }\end{array}$ & 7.167 & 8.667 & 10.167 & 9.417 & 11 \\
\hline 5 & $\begin{array}{l}\text { Petugas Radiologi } \\
\text { tidak sigap dalam } \\
\text { menangani pasien }\end{array}$ & 7.188 & 8.688 & 10.188 & 9.438 & 9 \\
\hline 6 & $\begin{array}{l}\text { Pelayanan yang } \\
\text { segera / cepat bagi } \\
\text { pasien }\end{array}$ & 7.104 & 8.604 & 10.104 & 9.354 & 14 \\
\hline 7 & $\begin{array}{lr}\text { Kesediaan } & \text { petugas } \\
\text { untuk } & \text { membantu } \\
\text { pasien } & \\
\end{array}$ & 7.250 & 8.750 & 10.250 & 9.500 & 5 \\
\hline 8 & $\begin{array}{lr}\text { Petugas } & \text { memberikan } \\
\text { informasi } & \text { yang jelas } \\
\text { kepada } & \text { pasien } \\
\text { seputar } & \text { pelayanan } \\
\text { Radiologi } & \\
\end{array}$ & 7.208 & 8.708 & 10.208 & 9.458 & 7 \\
\hline 9 & $\begin{array}{l}\text { Penanganan terhadap } \\
\text { keluhan pasien }\end{array}$ & 6.979 & 8.479 & 9.979 & 9.229 & 17 \\
\hline 10 & $\begin{array}{l}\text { Petugas mampu } \\
\text { membuat pasien } \\
\text { merasa aman saat } \\
\text { diberikan pelayanan }\end{array}$ & 7.313 & 8.813 & 10.313 & 9.563 & 1 \\
\hline 11 & $\begin{array}{l}\text { Petugas Radiologi } \\
\text { tidak terampil dalam } \\
\text { memberikan } \\
\text { pelayanan }\end{array}$ & 7.271 & 8.771 & 10.271 & 9.521 & 4 \\
\hline 12 & $\begin{array}{lr}\text { Petugas } & \text { mampu } \\
\text { menumbuhkan rasa } \\
\text { percaya } \\
\text { pasien }\end{array}$ & 7.083 & 8.583 & 10.083 & 9.333 & 16 \\
\hline 13 & $\begin{array}{l}\text { Petugas tidak mampu } \\
\text { menjawab pertanyaan } \\
\text { pasien }\end{array}$ & 7.313 & 8.813 & 10.313 & 9.563 & 3 \\
\hline 14 & $\begin{array}{l}\text { Kemudahan untuk } \\
\text { menghubungi Rumah } \\
\text { Sakit (Radiologi) }\end{array}$ & 7.229 & 8.729 & 10.229 & 9.479 & 6 \\
\hline 15 & $\begin{array}{l}\text { Petugas mampu } \\
\text { memahami kebutuhan } \\
\text { pasien }\end{array}$ & 6.938 & 8.438 & 9.938 & 9.188 & 19 \\
\hline 16 & $\begin{array}{l}\text { Petugas } \\
\text { memperlakukan } \\
\text { pasien penuh } \\
\text { perhatian }\end{array}$ & 6.938 & 8.438 & 9.938 & 9.188 & 18 \\
\hline 17 & $\begin{array}{l}\text { Petugas Radiologi } \\
\text { mampu } \\
\text { berkomunikasi } \\
\text { dengan baik dengan } \\
\text { pasien }\end{array}$ & 7.125 & 8.625 & 10.125 & 9.375 & 13 \\
\hline
\end{tabular}




\begin{tabular}{|c|c|c|c|c|c|c|}
\hline 18 & $\begin{array}{l}\text { Petugas yang ramah } \\
\text { dan sopan dalam } \\
\text { melayani pasien }\end{array}$ & 7.313 & 8.813 & 10.313 & 9.563 & 2 \\
\hline 19 & $\begin{array}{l}\text { Ruangan Radiologi } \\
\text { (ruang pemeriksaan, } \\
\text { ruang tunggu) yang } \\
\text { bersih, rapi, dan } \\
\text { nyaman }\end{array}$ & 7.104 & 8.604 & 10.104 & 9.354 & 15 \\
\hline 20 & $\begin{array}{lr}\text { Peralatan } & \text { yang } \\
\text { digunakan } & \\
\text { menggunakan } & \\
\text { teknologi } & \\
\text { (mutakhir) } & \\
\end{array}$ & 6.563 & 8.063 & 9.563 & 8.813 & 22 \\
\hline 21 & $\begin{array}{l}\text { Penampilan petugas } \\
\text { Radiologi yang rapi } \\
\text { dan sopan }\end{array}$ & 7.188 & 8.688 & 10.188 & 9.438 & 10 \\
\hline 22 & $\begin{array}{l}\text { Fasilitas yang } \\
\text { tersedia lengkap dan } \\
\text { memadai }\end{array}$ & 6.854 & 8.354 & 9.854 & 9.104 & 21 \\
\hline
\end{tabular}

\section{Sumber: Data Primer Tahun 2012}

Dari hasil pengolahan data persepsi pelanggan dan setelah di defuzzyfikasi, dapat diketahui nilai persepsi tertinggi dari kualitas pelayanan jasa Instalasi Radiologi RSUD Panembahan Senopati Bantul kepada pelanggan (pasien) adalah "Petugas mampu membuat pasien merasa aman saat diberikan pelayanan" dengan nilai 9,563. Hal ini di dukung dengan wawancara mendalam dengan pihak manajemen Instalasi Radiologi yaitu Informan 1 sebagai Kepala Instalasi Radiologi dan Informan 2 sebagai Koordinator Radiologi dan Penanggung Jawab Quality Control.

Untuk mengetahui kepuasan pelayanan, dapat dinilai dari keluhan atau komplain dari pasien. Untuk masalah kenyamanan dan keamanan, sejauh ini tidak ada komplain dari pasien. Untuk nilai terendah mengenai persepsi adalah "Peralatan yang digunakan menggunakan teknologi terbaru (mutakhir)" dengan nilai 8,813

\section{Perhitungan nilai Fuzzyfikasi harapan pelanggan}

Untuk menghitung nilai fuzzyfikasi kuesioner harapan pelanggan menggunakan software Ms. Excel, perhitunganyan sama seperti pada kuesioner persepsi pelanggan. Hasil perhitungannya dapat dilihat pada tabel 4.11 dibawah ini:

\section{Tabel 4.11 Hasil Rekapitulasi Data Harapan Pelanggan sesuai dengan Tingkat Kepentingan}

\begin{tabular}{llccccc}
\hline No & \multicolumn{1}{c}{ Kriteria } & $\begin{array}{c}\text { Sangat } \\
\text { Tidak } \\
\text { Baik } \\
(\mathbf{1})\end{array}$ & $\begin{array}{c}\text { Tidak } \\
\text { Baik } \\
\mathbf{( 2 )}\end{array}$ & $\begin{array}{c}\text { Cukup } \\
\text { Baik } \\
\mathbf{( 3 )}\end{array}$ & $\begin{array}{c}\text { Baik } \\
\mathbf{( 4 )}\end{array}$ & $\begin{array}{c}\text { Sangat } \\
\text { Baik } \\
\mathbf{( 5 )}\end{array}$ \\
\hline 1. & $\begin{array}{l}\text { Petugas memberikan } \\
\text { pelayanan } \\
\text { tepat }\end{array}$ & 0 & 1 & 16 & 17 & 62 \\
\hline 2. & Kesesuaran pelayanan & 0 & 0 & 11 & 37 & 48 \\
\hline
\end{tabular}




\begin{tabular}{|c|c|c|c|c|c|c|}
\hline & $\begin{array}{l}\text { dengan janji yang } \\
\text { ditawarkan }\end{array}$ & & & & & \\
\hline 3. & $\begin{array}{l}\text { Petugas memberikan } \\
\text { pelayanan sesuai } \\
\begin{array}{l}\text { dengan waktu yang } \\
\text { dijanikan }\end{array}\end{array}$ & 0 & 1 & 10 & 21 & 64 \\
\hline 4. & $\begin{array}{l}\text { Petugas tidak harus } \\
\text { membuat } \\
\text { medis }\end{array}$ & 1 & 3 & 15 & 20 & 57 \\
\hline 5. & $\begin{array}{l}\text { Petugas Radiologi } \\
\text { tidak sigap dalam } \\
\text { menangani pasien }\end{array}$ & 1 & 2 & 6 & 17 & 70 \\
\hline 6. & $\begin{array}{l}\text { Pelayanan } \\
\text { segera / cepat bagi } \\
\text { pasien }\end{array}$ & 0 & 0 & 4 & 34 & 58 \\
\hline 7. & $\begin{array}{lr}\text { Kesediaan } & \text { petugas } \\
\text { untuk } & \text { membantu } \\
\text { pasien } & \\
\end{array}$ & 0 & 0 & 3 & 27 & 66 \\
\hline 8. & $\begin{array}{l}\text { Petugas memberikan } \\
\text { informasi yang jelas } \\
\text { kepada pasien seputar } \\
\text { pelayanan Radiologi }\end{array}$ & 0 & 0 & 5 & 24 & 65 \\
\hline 9. & $\begin{array}{l}\text { Penanganan terhadap } \\
\text { keluhan pasien }\end{array}$ & 0 & 1 & 7 & 25 & 63 \\
\hline 10. & $\begin{array}{l}\text { Petugas mampu } \\
\text { membuat pasien } \\
\text { merasa aman saat } \\
\text { diberikan pelayanan }\end{array}$ & 1 & 0 & 6 & 32 & 57 \\
\hline 11. & $\begin{array}{l}\text { Petugas Radiologi } \\
\text { tidak terampil dalam } \\
\text { memberikan } \\
\text { pelayanan }\end{array}$ & 0 & 0 & 4 & 20 & 72 \\
\hline 12. & $\begin{array}{l}\text { Petugas mampu } \\
\text { menumbuhkan rasa } \\
\text { percaya kepada pasien }\end{array}$ & 0 & 0 & 8 & 32 & 56 \\
\hline 13. & $\begin{array}{l}\text { Petugas tidak mampu } \\
\text { menjawab pertanyaan } \\
\text { pasien }\end{array}$ & 3 & 1 & 7 & 14 & 71 \\
\hline 14. & $\begin{array}{l}\text { Kemudahan untuk } \\
\text { menghubungi Rumah } \\
\text { Sakit (Radiologi) }\end{array}$ & 2 & 0 & 4 & 32 & 58 \\
\hline 15. & $\begin{array}{l}\text { Petugas mampu } \\
\text { memahami } \\
\text { pasien }\end{array}$ & 1 & 0 & 5 & 35 & 55 \\
\hline 16. & $\begin{array}{l}\text { Petugas } \\
\text { memperlakukan pasien } \\
\text { penuh perhatian }\end{array}$ & 1 & 0 & 6 & 23 & 66 \\
\hline 17. & $\begin{array}{l}\text { Petugas } \text { Radiologi } \\
\text { mampu berkomunikasi } \\
\text { dengan baik dengan } \\
\text { pasien }\end{array}$ & 1 & 0 & 7 & 25 & 63 \\
\hline 18. & $\begin{array}{l}\text { Petugas yang raamah } \\
\text { dan sopan dalam } \\
\text { melayani pasien }\end{array}$ & 1 & 0 & 6 & 23 & 66 \\
\hline 19. & $\begin{array}{l}\text { Ruangan Radiologi } \\
\text { (ruang pemeriksaan, } \\
\text { ruang tunggu) yang }\end{array}$ & 1 & 1 & 4 & 21 & 69 \\
\hline
\end{tabular}




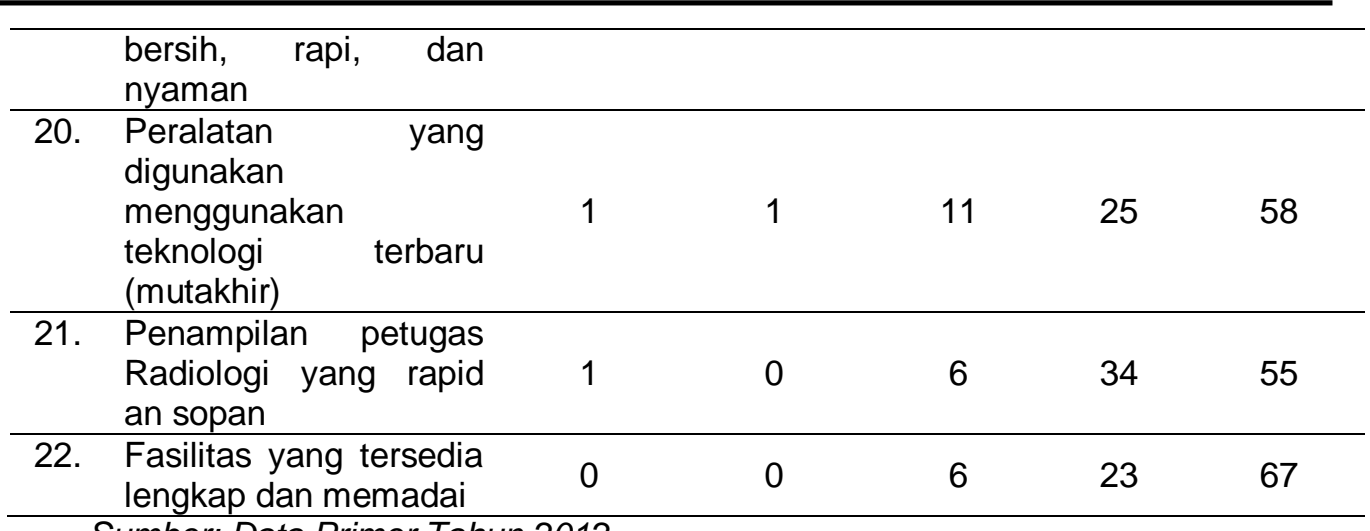

Sumber: Data Primer Tahun 2012

Sedangkan untuk mencari nilai fuzzyfikasi harapan pelanggan dengan menggunakan metode yang sama persepsi pelanggan. Hasil perhitungannya dapat dilihat pada tabel 4.12 sebagai berikut:

Tabel 4.12 Nilai Defuzzyfikasi Harapan Pelanggan

\begin{tabular}{|c|c|c|c|c|c|c|}
\hline \multirow{2}{*}{ No } & \multirow{2}{*}{ Kriteria } & \multicolumn{3}{|c|}{ TFN } & \multirow{2}{*}{$\begin{array}{c}\text { Defuzzy- } \\
\text { fikasi }\end{array}$} & \multirow[t]{2}{*}{ Rank } \\
\hline & & c & $\mathbf{a}$ & b & & \\
\hline 1 & $\begin{array}{l}\text { Petugas memberikan } \\
\text { pelayanan secara tepat }\end{array}$ & 7.917 & 9.417 & 10.917 & 10.167 & 19 \\
\hline 2 & Kesesuaian pelayanan & & & & & \\
\hline & $\begin{array}{l}\text { dengan janji yang } \\
\text { ditawarkan }\end{array}$ & 7.771 & 9.271 & 10.771 & 10.021 & 21 \\
\hline 3 & $\begin{array}{l}\text { Petugas memberikan } \\
\text { pelayanan sesuai dengan } \\
\text { waktu yang dijanjikan }\end{array}$ & 8.083 & 9.583 & 11.083 & 10.333 & 12 \\
\hline 4 & $\begin{array}{l}\text { Petugas tidak harus } \\
\text { membuat catatan medis }\end{array}$ & 7.688 & 9.188 & 10.688 & 9.938 & 22 \\
\hline 5 & $\begin{array}{l}\text { Petugas Radiologi tidak } \\
\text { sigap dalam menangani } \\
\text { pasien }\end{array}$ & 8.188 & 9.688 & 11.188 & 10.438 & 5 \\
\hline 6 & $\begin{array}{l}\text { Pelayanan yang segera / } \\
\text { cepat bagi pasien }\end{array}$ & 8.125 & 9.625 & 11.125 & 10.375 & 8 \\
\hline 7 & $\begin{array}{l}\text { Kesediaan petugas untuk } \\
\text { membantu pasien }\end{array}$ & 8.313 & 9.813 & 11.313 & 10.563 & 2 \\
\hline 8 & $\begin{array}{l}\text { Petugas memberikan } \\
\text { informasi yang jelas } \\
\text { kepada pasien seputar } \\
\text { pelayanan Radiologi }\end{array}$ & 8.104 & 9.573 & 11.042 & 10.307 & 13 \\
\hline 9 & $\begin{array}{ll}\text { Penanganan } & \text { terhadap } \\
\text { keluhan pasien }\end{array}$ & 8.125 & 9.625 & 11.125 & 10.375 & 9 \\
\hline 10. & $\begin{array}{ll}\text { Petugas } & \text { mampu } \\
\text { membuat pasien merasa } \\
\text { aman saat diberikan } \\
\text { pelayanan }\end{array}$ & 8.000 & 9.500 & 11.000 & 10.250 & 14 \\
\hline 11 & $\begin{array}{lr}\text { Petugas } & \text { mampu } \\
\text { menumbuhkan } & \text { rasa } \\
\text { percaya kepada pasien }\end{array}$ & 8.417 & 9.917 & 11.417 & 10.667 & 1 \\
\hline 12 & $\begin{array}{lr}\text { Petugas } & \text { Radiologi } \\
\text { terampil } & \text { dalak } \\
\end{array}$ & 8.000 & 9.500 & 11.000 & 10.250 & 15 \\
\hline
\end{tabular}




\begin{tabular}{|c|c|c|c|c|c|c|}
\hline & memberikan pelayanan & & & & & \\
\hline 13 & $\begin{array}{l}\text { Petugas tidak mampu } \\
\text { menjawab pertanyaan } \\
\text { pasien }\end{array}$ & 8.104 & 9.604 & 11.104 & 10.354 & 11 \\
\hline 14 & $\begin{array}{lr}\text { Kemudahan } & \text { untuk } \\
\text { menghubungi } & \text { Rumah } \\
\text { Sakit (Radiologi) } & \\
\end{array}$ & 8.000 & 9.500 & 11.000 & 10.250 & 16 \\
\hline 15 & $\begin{array}{lr}\text { Petugas } & \text { mampu } \\
\text { memahami } & \text { kebutuhan } \\
\text { pasien } & \\
\end{array}$ & 7.979 & 9.479 & 10.979 & 10.229 & 17 \\
\hline 16 & $\begin{array}{l}\text { Petugas memperlakukan } \\
\text { pasien penuh perhatian }\end{array}$ & 8.188 & 9.688 & 11.188 & 10.438 & 7 \\
\hline 17 & $\begin{array}{lr}\text { Petugas } & \text { Radiologi } \\
\text { mampu berkomunikasi } \\
\text { dengan baik dengan } \\
\text { pasien }\end{array}$ & 8.104 & 9.604 & 11.104 & 10.354 & 10 \\
\hline 18 & $\begin{array}{l}\text { Petugas yang ramah dan } \\
\text { sopan dalam melayani } \\
\text { pasien }\end{array}$ & 8.188 & 9.688 & 11.188 & 10.438 & 6 \\
\hline 19 & $\begin{array}{l}\text { Ruangan Radiologi } \\
\text { (ruang pemeriksaan, } \\
\text { ruang tunggu) yang } \\
\text { bersih, rapi, dan nyaman }\end{array}$ & 8.250 & 9.750 & 11.250 & 10.500 & 4 \\
\hline 20 & $\begin{array}{lr}\text { Peralatan } & \text { yang } \\
\text { digunakan } & \text { menggunakan } \\
\text { teknologi } & \text { terbaru } \\
\text { (mutakhir) } & \\
\end{array}$ & 7.875 & 9.375 & 10.875 & 10.125 & 20 \\
\hline 21. & $\begin{array}{l}\text { Penampilan petugas } \\
\text { Radiologi yang rapi dan } \\
\text { sopan }\end{array}$ & 7.958 & 9.458 & 10.958 & 10.208 & 18 \\
\hline 22 & $\begin{array}{l}\text { Fasilitas yang tersedia } \\
\text { lengkap dan memadai }\end{array}$ & 8.271 & 9.771 & 11.271 & 10.521 & 3 \\
\hline
\end{tabular}

Dari hasil pengolahan data harapan pelanggan dan setelah di defuzzyfikasi dengan menggunakan software Ms. Excel dapat diketahui nilai harapan tertinggi dari kualitas pelayanan jasa Instalasi Radiologi RSUD Panembahan Senopati Bantul kepada pelanggan adalah "Petugas mampu menumbuhkan rasa percaya kepada pasien" dengan nilai 10,667, seperti yang dikemukakan oleh Kepala Radiologi

\section{Perhitungan nilai Servqual (gap) per kriteria}

Hasil perhitungan nilai servqual (gap) per kriteria dari selisih tingkat persepsi dan harapan menunjukkan sejauh mana pihak manajemen rumah sakit telah memberikan pelayanan sesuai dengan keinginan pelanggannya (pasien). Peran gap per kriteria akan memberikan tingkat kepentingan seberapa jauh peran kriteria tersebut dalam memberikan Tingkat Kualitas Pelayanan. Hasilnya dapat dilihat pada tabel 4.13 sebagai berikut:

Tabel 4.13 Nilai Servqual (Gap) per kriteria antara Persepsi dan Harapan pelanggan

\begin{tabular}{cccccc}
\hline No & Kriteria & Persepsi & Harapan & Gap & Rank \\
\hline 1 & $\begin{array}{l}\text { Petugas } \\
\text { pelayanan secara tepat }\end{array}$ & 9.438 & 10.167 & -0.729 & 20 \\
\hline
\end{tabular}




\begin{tabular}{|c|c|c|c|c|c|}
\hline \multirow[t]{2}{*}{2} & \multicolumn{5}{|l|}{ Kesesuaian pelayanan } \\
\hline & $\begin{array}{l}\text { dengan janji yang } \\
\text { ditawarkan }\end{array}$ & 9.188 & 10.021 & -0.833 & 16 \\
\hline 3 & $\begin{array}{l}\text { Petugas memberikan } \\
\text { pelayanan sesuai dengan } \\
\text { waktu yang dijanikan }\end{array}$ & 9.383 & 10.333 & -0.951 & 12 \\
\hline 4 & $\begin{array}{l}\text { Petugas tidak harus } \\
\text { membuat catatan medis }\end{array}$ & 9.417 & 9.938 & -0.521 & 22 \\
\hline 5 & $\begin{array}{l}\text { Petugas Radiologi tidak } \\
\text { sigap dalam menangani } \\
\text { pasien }\end{array}$ & 9.438 & 10.438 & -1.000 & 10 \\
\hline 6 & $\begin{array}{l}\text { Pelayanan yang segera / } \\
\text { cepat bagi pasien }\end{array}$ & 9.354 & 10.375 & -1.021 & 9 \\
\hline 7 & $\begin{array}{l}\text { Kesediaan petugas untuk } \\
\text { membantu pasien }\end{array}$ & 9.500 & 10.563 & -1.063 & 7 \\
\hline 8 & $\begin{array}{lr}\text { Petugas } & \text { memberikan } \\
\text { informasi yang jelas } \\
\text { kepada pasien seputar } \\
\text { pelayanan Radiologi }\end{array}$ & 9.458 & 10.307 & -0.849 & 15 \\
\hline 9 & $\begin{array}{ll}\text { Penanganan } & \text { terhadap } \\
\text { keluhan pasien } & \end{array}$ & 9.229 & 10.375 & -1.146 & 4 \\
\hline 10 & $\begin{array}{l}\text { Petugas mampu membuat } \\
\text { pasien merasa aman saat } \\
\text { diberikan pelayanan }\end{array}$ & 9.563 & 10.250 & -0.688 & 21 \\
\hline 11 & $\begin{array}{l}\text { Petugas Radiologi tidak } \\
\text { terampil dalam } \\
\text { memberikan pelayanan }\end{array}$ & 9.521 & 10.667 & -1.146 & 6 \\
\hline 12 & $\begin{array}{l}\text { Petugas mampu } \\
\text { menumbuhkan rasa } \\
\text { percaya kepada pasien }\end{array}$ & 9.333 & 10.250 & -0.917 & 13 \\
\hline 13 & $\begin{array}{l}\text { Petugas tidak mampu } \\
\text { menjawab } \\
\text { pasien }\end{array}$ & 9.563 & 10.354 & -0.792 & 17 \\
\hline 14 & $\begin{array}{l}\text { Kemudahan untuk } \\
\text { menghubungi Rumah Sakit } \\
\text { (Radiologi) }\end{array}$ & 9.479 & 10.250 & -0.771 & 19 \\
\hline 15 & $\begin{array}{lr}\text { Petugas } & \text { mampu } \\
\text { memahami } & \text { kebutuhan } \\
\text { pasien } & \\
\end{array}$ & 9.188 & 10.229 & -1.042 & 8 \\
\hline 16 & $\begin{array}{l}\text { Petugas memperlakukan } \\
\text { pasien penuh perhatian }\end{array}$ & 9.188 & 10.438 & -1.250 & 3 \\
\hline 17 & $\begin{array}{l}\text { Petugas Radiologi mampu } \\
\text { berkomunikasi dengan } \\
\text { baik dengan pasien }\end{array}$ & 9.375 & 10.354 & -0.979 & 11 \\
\hline 18 & $\begin{array}{l}\text { Petugas yang ramah dan } \\
\text { sopan dalam melayani } \\
\text { pasien }\end{array}$ & 9.563 & 10.438 & -0.875 & 14 \\
\hline 19 & $\begin{array}{l}\text { Ruangan Radiologi (ruang } \\
\text { pemeriksaan, ruang } \\
\text { tunggu) yang bersih, rapi, } \\
\text { dan nyaman }\end{array}$ & 9.354 & 10.500 & -1.146 & 5 \\
\hline 20 & $\begin{array}{l}\text { Peralatan yang digunakan } \\
\text { menggunakan teknologi } \\
\text { terbaru (mutakhir) }\end{array}$ & 8.813 & 10.125 & -1.313 & 2 \\
\hline 21 & Penampilan & 9.438 & 10.208 & -0.771 & 18 \\
\hline
\end{tabular}




\begin{tabular}{llllll}
\hline & $\begin{array}{l}\text { Radiologi yang rapi dan } \\
\text { sopan }\end{array}$ & & & & \\
\hline 22 & $\begin{array}{l}\text { Fasilitas yang tersedia } \\
\text { lengkap dan memadai }\end{array}$ & 9.104 & 10.521 & -1.417 & 1 \\
\hline
\end{tabular}

\section{Sumber: Data Primer Tahun 2012}

Dari hasil perhitungan nilai servqual (gap) per kriteria diperoleh lima kriteria yang perlu menjadi prioritas untuk dilakukan perbaikan dan peningkatan kualitas pelayanan. Berikut ini adalah lima kriteria dengan nilai servqual terbesar yang harus menjadi perhatian RSUD Panembahan Senopati Bantul, yaitu :

Tabel 4.14 Nilai Servqual Per Kriteria Terbesar

\begin{tabular}{clcc}
\hline No & \multicolumn{1}{c}{ Kriteria } & Nilai Servqual & Rank \\
\hline 1 & $\begin{array}{l}\text { Fasilitas yang tersedia lengkap } \\
\text { dan memadai }\end{array}$ & $-1,417$ & 1 \\
\hline 2 & $\begin{array}{l}\text { Peralatan yang digunakan } \\
\text { menggunakan } \\
\text { terbaru (mutakhir) }\end{array}$ & $-1,313$ & 2 \\
\hline 3 & $\begin{array}{l}\text { Petugas memperlakukan } \\
\text { pasien penuh perhatian }\end{array}$ & $-1,250$ & 3 \\
\hline 4 & $\begin{array}{l}\text { Penanganan terhadap keluhan } \\
\text { pasien }\end{array}$ & $-1,146$ & 4 \\
\hline 5 & $\begin{array}{l}\text { Ruangan Radiologi (ruang } \\
\text { pemeriksaan, ruang tunggu) } \\
\text { yang bersih, rapi, dan nyaman }\end{array}$ & $-1,146$ & 5 \\
\hline & Sumber: Data Primer Tahun 2012 & &
\end{tabular}

Dari tabel diatas diketahui bahwa kriteria yang mempunyai nilai servqual terbesar adalah Fasilitas yang tersedia lengkap dan memadai dengan nilai servqual sebesar $-1,417$, untuk urutan kedua Peralatan yang digunakan menggunakan teknologi terbaru (mutakhir) sebesar 1,313 , Petugas memperlakukan pasien penuh perhatian menduduki urutan ketiga dengan nilai $-1,250$, untuk urutan keempat dan yang terakhir yaitu Penanganan terhadap keluhan dan Ruangan radiologi yang bersih, rapi, nyaman sebesar -1,146. Hal tersebut didukung oleh pernyataan pihak manajemen, yaitu:

1. Fasilitas yang tersedia belum lengkap dan memadai

2. Peralatan yang digunakan belum menggunakan teknologi terbaru (mutakhir)

3. Petugas belum sepenuhnya memperlakukan pasien dengan penuh perhatian

4. Penanganan terhadap keluhan pasien

5. Ruangan Radiologi (ruang tunggu) yang belum nyaman

\section{Perhitungan nilai Servqual (gap) per dimensi}

Hasil perhitungan nilai Servqual (gap) per dimensi dari selisih tingkat persepsi dan harapan menunjukkan sampai sejauh mana pihak manajemen Rumah Sakit Panembahan Senopati Bantul telah memberikan pelayanan sesuai dengan keinginan pelanggannya. Peran gap per dimensi akan memberikan tingkat kepentingan seberapa jauh 
peran kelima dimensi tersebut dalam memberikan informasi tentang tingkat kualitas pelayanan. Hasilnya dapat dilihat pada tabel 4.15 sebagai berikut:

Tabel 4.15 Nilai Servqual (Gap) per dimensi antara Persepsi dan Harapan Pelanggan

\begin{tabular}{|c|c|c|c|c|c|}
\hline No & Kriteria & Persepsi & Harapan & Gap & Rank \\
\hline & A. Reliability (Kehandalan) & & & & \\
\hline 1. & $\begin{array}{ll}\text { Petugas } & \text { memberikan } \\
\text { pelayanan secara tepat }\end{array}$ & 9.438 & 10.167 & & \\
\hline 2. & $\begin{array}{l}\text { Kesesuaian pelayanan dengan } \\
\text { janji yang ditawarkan }\end{array}$ & 9.188 & 10.021 & & \\
\hline 3. & $\begin{array}{l}\text { Petugas memberikan } \\
\text { pelayanan sesuai dengan } \\
\text { waktu yang dijanikan }\end{array}$ & 9.383 & 10.333 & & \\
\hline \multirow[t]{3}{*}{4.} & $\begin{array}{l}\text { Petugas tidak harus membuat } \\
\text { catatan medis }\end{array}$ & 9.417 & 9.938 & & \\
\hline & Jumlah & 9.356 & 10.115 & -0.758 & 5 \\
\hline & $\begin{array}{l}\text { B. Responsiveness (Daya } \\
\text { Tanggap) }\end{array}$ & & & & \\
\hline 5. & $\begin{array}{l}\text { Petugas Radiologi tidak sigap } \\
\text { dalam menangani pasien }\end{array}$ & 9.438 & 10.438 & & \\
\hline 6. & $\begin{array}{l}\begin{array}{l}\text { Pelayanan yang segera } \\
\text { cepat bagi pasien }\end{array} \\
\end{array}$ & 9.354 & 10.375 & & \\
\hline 7. & $\begin{array}{l}\text { Kesediaan petugas untuk } \\
\text { membantu pasien }\end{array}$ & 9.500 & 10.563 & & \\
\hline 8. & $\begin{array}{lr}\text { Petugas } & \text { memberikan } \\
\text { informasi yang jelas kepada } \\
\text { pasien seputar pelayanan } \\
\text { Radiologi }\end{array}$ & 9.458 & 10.307 & & \\
\hline \multirow[t]{3}{*}{9.} & $\begin{array}{l}\text { Penanganan terhadap keluhan } \\
\text { pasien }\end{array}$ & 9.229 & 10.375 & & \\
\hline & Jumlah & 9.396 & 10.411 & -1.016 & 2 \\
\hline & C. Assurance (Jaminan) & & & & \\
\hline 10. & $\begin{array}{l}\text { Petugas mampu membuat } \\
\text { pasien merasa aman saat } \\
\text { diberikan pelayanan }\end{array}$ & 9.563 & 10.250 & & \\
\hline 11. & $\begin{array}{l}\text { Petugas Radiologi tidak } \\
\text { terampil dalam memberikan } \\
\text { pelayanan }\end{array}$ & 9.521 & 10.667 & & \\
\hline 12. & 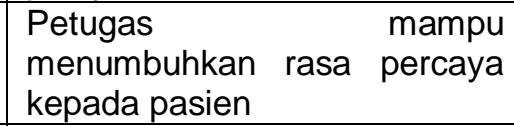 & 9.333 & 10.250 & & \\
\hline \multirow[t]{3}{*}{13.} & $\begin{array}{l}\text { Petugas tidak mampu } \\
\text { menjawab pertanyaan pasien }\end{array}$ & 9.563 & 10.354 & & \\
\hline & Jumlah & 9.495 & 10.380 & -0.885 & 4 \\
\hline & D. Emphaty (Empati) & & & & \\
\hline 14. & $\begin{array}{lrc}\text { Kemudahan } & \text { untuk } \\
\text { menghubungi } & \text { Rumah } & \text { Sakit }\end{array}$ & 9.479 & 10.250 & & \\
\hline
\end{tabular}




\begin{tabular}{|c|c|c|c|c|c|}
\hline & (Radiologi) & & & & \\
\hline 15. & $\begin{array}{l}\text { Petugas mampu memahami } \\
\text { kebutuhan pasien }\end{array}$ & 9.188 & 10.229 & & \\
\hline 16. & $\begin{array}{l}\text { Petugas memperlakukan } \\
\text { pasien penuh perhatian }\end{array}$ & 9.188 & 10.438 & & \\
\hline 17. & $\begin{array}{l}\text { Petugas Radiologi mampu } \\
\text { berkomunikasi dengan baik } \\
\text { dengan pasien }\end{array}$ & 9.375 & 10.354 & & \\
\hline \multirow[t]{3}{*}{18.} & $\begin{array}{l}\text { Petugas yang ramah dan } \\
\text { sopan dalam melayani pasien }\end{array}$ & 9.563 & 10.438 & & \\
\hline & Jumlah & 9.358 & 10.342 & -0.983 & 3 \\
\hline & $\begin{array}{l}\text { E. Tangibles (Bukti } \\
\text { Langsung) }\end{array}$ & & & & \\
\hline 19. & $\begin{array}{l}\text { Ruangan Radiologi (ruang } \\
\text { pemeriksaan, ruang tunggu) } \\
\text { yang bersih, rapi, dan nyaman }\end{array}$ & 9.354 & 10.500 & & \\
\hline 20. & $\begin{array}{lr}\text { Peralatan yang } & \text { digunakan } \\
\text { menggunakan } & \text { teknologi } \\
\text { terbaru (mutakhir) } & \end{array}$ & 8.813 & 10.125 & & \\
\hline 21. & $\begin{array}{l}\text { Penampilan petugas Radiologi } \\
\text { yang rapi dan sopan }\end{array}$ & 9.438 & 10.208 & & \\
\hline 22. & $\begin{array}{l}\text { Fasilitas yang tersedia lengkap } \\
\text { dan memadai }\end{array}$ & 9.104 & 10.521 & & \\
\hline & Jumlah & 9.177 & 10.339 & -1.161 & 1 \\
\hline
\end{tabular}

Dari hasil perhitungan nilai Servqual (gap) per dimensi, yang menempati ranking pertama adalah dimensi Tangibles sebesar $-1,161$, seperti halnya pada hasil perhitungan per kriteria dimana tiga kriteria yang menjadi prioritas merupakan bagian dari dimensi Tangibles. Untuk urutan kedua yaitu dimensi Responsiveness sebesar -1,016, urutan ketiga yaitu dimensi Emphaty sebesar -0,983, urutan keempat yaitu dimensi Assurance sebesar -0,885, dan yang terakhir atau urutan kelima yaitu Realibility sebesar $-0,758$.

\section{Perhitungan nilai Servqual (gap) keseluruhan}

Hasil perhitungan nilai Servqual (gap) secara keseluruhan dari selisih tingkat persepsi dan harapan menunjukkan sampai sejauh mana pihak manajemen Rumah Sakit Panembahan Senopati Bantul telah memberikan pelayanan sesuai dengan keinginan pelanggannya. Peran gap keseluruhan akan memberikan informasi seberapa besar tingkat kepentingan dan seberapa jauh peran kriteria tersebut dalam tingkat kualitas pelayanan. Hasilnya dapat dilihat pada tabel 4.16 berikut ini:

Tabel 4.16 Nilai Servqual (Gap) keseluruhan antara Persepsi dan Harapan pelanggan

\begin{tabular}{|c|c|c|c|c|c|}
\hline No & Dimensi & Persepsi & Harapan & Gap & Rank \\
\hline 1 & Tangibles & 9.177 & 10.339 & -1.161 & 1 \\
\hline 2 & Responsiveness & 9.396 & 10.411 & -1.016 & 2 \\
\hline 3 & Emphaty & 9.358 & 10.342 & -0.983 & 3 \\
\hline 4 & Assurance & 9.495 & 10.380 & -0.885 & 4 \\
\hline 5 & Realibility & 9.356 & 10.115 & -0.758 & 5 \\
\hline \multicolumn{2}{|r|}{ Total } & $\mathbf{9 . 3 5 6}$ & $\mathbf{1 0 . 3 1 7}$ & $\mathbf{- 0 . 9 6 1}$ & \\
\hline
\end{tabular}


Dari hasil perhitungan gap secara keseluruhan menunjukkan bahwa nilai gap negatif yaitu $-0,961$ yang berarti bahwa apa yang diharapkan pelanggan belum semua sesuai dengan apa yang diperoleh pelanggan di Instalasi Radiologi Rumah Sakit Panembahan Senopati Bantul.

\section{B. Pembahasan}

\section{a. Penghitungan Nilai Defuzzyfikasi Persepsi Pelanggan}

Dari hasil pengolahan data persepsi pelanggan yang telah di defuzzyfikasi dengan menggunakan software Ms. Excel diketahui nilai persepsi tertinggi dari kualitas pelayanan jasa Instalasi Radiologi RSUD Panembahan Senopati Bantul kepada pelanggan (pasien) adalah "Petugas mampu membuat pasien merasa aman saat diberikan pelayanan" dengan nilai 9,563. Seperti yang terdapat pada misi di Instalasi Radiologi yaitu Memberikan pelayanan radiodiagnostik sesuai dengan standar operasional prosedur (SOP) yang telah ditetapkan dengan selalu mengutamakan azas proteksi radiasi serta keamanan dan kenyamanan pasien. Hal ini juga sesuai dengan pernyataan dari pihak manajemen yang menyatakan bahwa untuk masalah kenyamanan dan keamanan sejauh ini tidak ada komplain dari pasien.

Komplain merupakan indikator untuk menilai tingkat kinerja perusahaan (Perceived Performance) dimana menurut Oliver (1997) Perceived Performance dirumuskan sebagai persepsi terhadap jumlah atribut produk atau jasa dari hasil yang diterima. Pada umumnya kinerja atau hasil yang dirasakan merupakan persepsi pelanggan terhadap apa yang ia terima setelah mengkonsumsi produk yang ia beli. Kotler (2009) mendefinisikan Persepsi (Perception) sebagai proses dimana kita memilih, mengatur, menerjemahkan masukan informasi untuk menciptakan gambaran dunia yang berarti.

Sedangkan untuk nilai terendah dari perhitungan nilai defuzzyfikasi persepsi pelanggan adalah "Peralatan yang digunakan belum menggunakan teknologi terbaru (mutakhir)" dengan nilai 8,813. Sesuai dengan pernyataan manajemen yang mengatakan bahwa alat yang digunakan di Instalasi Radiologi masih menggunakan alat konvensional tapi keadaannya masih cukup bagus dan memadai. Namun bila pasien yang foto radiologi banyak akan terjadinya antrian yang panjang karena pasien cenderung menggunakan pada satu alat pemeriksaan saja yang akan membuat pelayanan menjadi lama, dimana hal ini banyak dikeluhkan/dikomplain pasien mengenai waktu tunggu yang lama. Tjiptono \& Chandra (2011) mengemukakan jasa yang dipersepsikan pelangan (perceived service) merupakan hasil dari serangkaian keputusan dan aktivitas internal perusahaan yang akan menimbulkan suatu penilaian kualitas pelayanan yaitu sikap individu secara umum terhadap kinerja perusahaan. 


\section{b. Penghitungan Nilai Deffuzyfikasi Harapan Pelanggan}

Dari hasil pengolahan data harapan pelanggan dan setelah di defuzzyfikasi dengan menggunakan software Ms. Excel dapat diketahui nilai harapan tertinggi dari kualitas pelayanan jasa Instalasi Radiologi RSUD Panembahan Senopati Bantul kepada pelanggan adalah "Petugas mampu menumbuhkan rasa percaya kepada pasien" dengan nilai 10,667. Sama seperti keterangan yang dari pihak manajemen yang mengatakan bahwa dengan bekerja sesuai dengan prosedur dan dengan disiplin yang tinggi dari petugas, akan menciptakan rasa kepercayaan pasien kepada petugas. Menurut Yamit (2010) dengan memberikan pelayanan terbaik pada pelangaan (excellent) merupakan cara terbaik yang konsisten untuk dapat mempertemukan harapan konsumen dan sistem kinerja cara pelayanan. Olson \& Dover mendefinisikan Harapan/ekspektasi pelanggan merupakan keyakinan pelanggan sebelum mencoba atau membeli suatu produk, yang dijadikan standar atau acuan dalam menilai kinerja produk bersangkutan.

Untuk nilai terendah dari perhitungan nilai defuzzyfikasi harapan pelanggan adalah adalah "Petugas harus membuat catatan medis" dengan nilai 9,938. Menurut Permenkes no.269/2008 \& UU no.29/2004, Catatan medis atau Rekam Medis berarti berkas berisi catatan dan dokumen tentang pasien yang berisi identitas, pemeriksaan, pengobatan, tindakan medis lain pada sarana pelayanan kesehatan untuk rawat jalan, rawat inap baik dikelola pemerintah maupun swasta. Banyak diantara pasien yang tidak tau atau tidak mengerti pentingnya Rekam Medis sehingga mereka menganggap tidak begitu penting dalam suatu pelayanan. Dikarenakan kebanyakan lulusan responden sebagian besar berpendidikan SMA dengan jumlah 26 responden $(27,1 \%)$ dari total responden 96 orang.

\section{c. Penghitungan Nilai Servqual (gap) per kriteria antara Persepsi dan Harapan Pelanggan.}

Dari hasil penghitungan nilai Servqual (gap) per kriteria dari selisih tingkat persepsi dan harapan menunjukkan sampai sejauh mana pihak RSUD Panembahan Senopati Bantul terutama Instalasi Radiologi telah memberikan pelayanan sesuai dengan keinginan pelanggan. Peran bobot dalam gap akan memberikan tingkat kepentingan seberapa jauh peran kriteria tersebut dalam memberikan peningkatan kualitas pelayanan.

Dari hasil perhitungan nilai servqual (gap) per kriteria diperoleh lima kriteria yang perlu menjadi prioritas untuk dilakukan perbaikan dan peningkatan kualitas pelayanan seperti pada tabel 4.14 diatas.

Dari tabel 4.14 diatas diketahui bahwa kriteria yang mempunyai nilai servqual terbesar adalah Fasilitas yang tersedia belum lengkap dan memadai dengan nilai servqual sebesar -1,417, untuk urutan kedua Peralatan yang digunakan belum menggunakan teknologi terbaru (mutakhir) sebesar -1,313, Petugas belum sepenuhnya memperlakukan pasien dengan penuh perhatian menduduki urutan ketiga dengan nilai 1,250, untuk urutan keempat dan yang terakhir yaitu Penanganan terhadap keluhan dan Ruangan radiologi (ruang tunggu) yang belum nyaman sebesar $-1,146$.

Berdasarkan hasil wawancara yang dilakukan dengan pihak manajemen, diketahui bahwa untuk fasilitas informasi tentang alur pelayanan Instalasi Radiologi masih kurang seperti keluhan yang 
disampaikan pasien kepada pihak manajemen. Untuk alat yang digunakan di Instalasi radiologi juga masih menggunakan alat konvensional (belum komputerist) tapi kondisinya cukup baik dan memadai. Namun bila pasien yang memeriksa banyak, maka akan terjadi antrian yang cukup panjang karena pasien cenderung menggunakan pada satu alat yang akan membuat pelayanan menjadi lama. Mengenai sikap petugas, memang ada petugas yang kurang ramah dan tidak disiplin tapi hanya beberapa orang saja, secara keseluruhan sudah baik. Untuk penanganan terhadap keluhan dari pasien yaitu dengan memberikan pengertian dan penjelasan kepada pasien mengenai hal yang dikomplainkan oleh pasien dan dicari penyebab masalahnya dan lebih meningkatkan kemampuan dan keterampilan petugas.

Sedangkan untuk masalah ruang radiologi (ruang tunggu) yang masih belum nyaman, berdasarkan hasil observasi yang dilakukan peneliti diketahui bahwa antara ruang pendaftaran dan ruang pengambilan hasil foto masih berada dalam satu tempat dimana hal ini membuat pasien bingung dan tidak nyaman. Dan seperti yang dikemukakan oleh pihak manajemen, bahwa banyak didapati pasien merasa bingung menunggu dimana setelah mendaftar dan setelah diperiksa karena tempat pemanggilan yang tidak berhadapan langsung dengan pasien. Karena layout / tata letak ruangan yang kurang efektif sehingga menyebabkan pasien merasa bingung dan tidak nyaman.

Upaya yang telah dilakukan oleh pihak manajemen rumah sakit untuk mengatasi masalah fasilitas informasi tentang alur pelayanan Instalasi Radiologi yaitu dengan menambahkan pengeras suara. Sedangkan upaya untuk penanganan terhadap keluhan dari pasien yaitu mengadakan evaluasi terhadap masalah yang dikeluhkan pasien. Evaluasi dilakukan setiap satu bulan sekali pada saat rapat. Selain itu juga diadakan kotak saran dan sms center untuk menangani keluhan dari pasien, dan penyebaran kuesioner. Untuk meningkatkan keterampilan petugas dilakukan pelatihan seperti workshop atau seminar.

Kualitas layanan tiap kriteria dipresentasikan dengan nilai gap yang diperoleh. Menurut Parasuraman, et al, (1985) kualitas jasa bisa diwujudkan melalui pemenuhan kebutuhan dan keinginan pelanggan serta ketepatan penyampaiannya untuk mengimbangi harapan pelanggan. Nilai gap yang negatif menunjukkan bahwa kualitas layanan suatu kriteria kurang baik sehingga perlu ditingkatkan. Idealnya nilai gap sama dengan nol, dimana nilai persepsi sama dengan harapan pelanggan, sehingga dapat dikatakan persepsi sudah sesuai dengan harapan yang mengindikasikan kriteria kualitas layanan. Untuk itu kriteria harus dipertahankan. Apabila nilai yang diperoleh adalah positif, berati persepsi melebihi harapan pelanggan. Semakin besar nilai negatif suatu gap, maka kriteria tersebut menjadi prioritas utama untuk ditingkatkan kualitasnya. Tjiptono \& Chandra (2011) berpendapat baik tidaknya kualitas jasa tergantung pada kemampuan perusahaan/penyedia jasa dalam memenuhi harapan pelanggannya secara konsisten. Karena kinerja produk atau jasa pada berbagai atribut atau per kriteria dibandingkan dengan haparan/ekspektasi. Perbandingan tersebut akan menghasilkan reaksi konsumen terhadap produk atau jasa dalam bentuk kepuasan atau persepsi kualitas. 


\section{d. Penghitungan Nilai Servqual (Gap) per dimensi antara Persepsi dan Harapan Pelanggan.}

Perhitungan nilai Servqual (gap) per dimensi dari selisih tingkat persepsi dan harapan menunjukkan sampai sejauh mana pihak manajemen Rumah Sakit Panembahan Senopati Bantul telah memberikan pelayanan sesuai dengan keinginan pelanggannya. Peran gap per dimensi akan memberikan tingkat kepentingan seberapa jauh peran kelima dimensi tersebut dalam memberikan informasi tentang tingkat kualitas pelayanan. Perangkingan nilai Servqual (gap) per dimensi antar persepsi dan harapan pelanggan ini bertujuan mengetahui dimensi mana yang masih banyak kekurangan dan di prioritaskan untuk segera diperbaiki oleh manajemen.

Hasil perhitungan gap per dimensi menunjukkan bahwa dimensi Tangibles menempati ranking pertama dengan jumlah skor -1,161, kemudian diikuti dimensi Responsiveness menempati ranking kedua dengan skor -1.016, disusul ranking tiga dan empat yaitu dimensi Emphaty dan Assurance dengan skor masing-masing sebesar -0,983 dan $-0,885$ dan ranking terakhir adalah dimensi Realibility dengan skor $-0,758$. Hal ini menunjukkan bahwa kriteria-kriteria dalam dimensi Tangibles perlu atau lebih diprioritaskan untuk dilakukan peningkatan seperti halnya pada hasil perhitungan per kriteria dimana tiga kriteria yang menjadi prioritas merupakan bagian dari dimensi Tangibles yaitu fasilitas yang belum memadai, alat yang digunakan belum menggunakan peralatan terbaru (mutakhir), dan ruang radiologi (ruang tunggu) yang kurang nyaman.

Berdasarkan wawancara dengan pasien dan didukung pernyataan dari pihak manajemen, didapatkan hasil bahwa pasien banyak mengeluhkan atau komplain waktu tunggu yang lama. Lama pelayanan dapat disebabkan karena proses yang lama atau antrian yang panjang. Dapat juga disebabkan karena keterbatasan alat, dimana pasien yang memeriksa banyak. Menurut Brady dan Cronin (2001) waktu tunggu yang diukur bukanlah waktu tunggu absolut, namun persepsi pelanggan terhadap lamanya waktu menunggu penyampaian jasa. Secara metodologis, pengukuran waktu tunggu absolut secara ketat membutuhkan desain riset eksperimental dan bukan sekedar survei pelanggan. Goetsch Davis (1994) mendefinisikan Kualitas merupakan suatu kondisi dinamis yang berhubungan dengan produk, jasa, manusia, proses, dan lingkungan yang memenuhi atau melebihi harapan. Perusahaan jasa dan pelayanan lebih menekankan pada kualitas proses, karena konsumen biasanya terlibat langsung dalam proses tersebut.

\section{e. Penghitungan nilai Servqual (Gap) keseluruhan antara Persepsi dan Harapan pelanggan.}

Peran gap keseluruhan akan memberikan informasi seberapa besar tingkat kepentingan dan seberapa jauh peran kriteria tersebut dalam tingkat kualitas pelayanan. Hasil perhitungan gap secara keseluruhan menunjukkan bahwa nilai gap negatif sebesar -0.961 , berarti apa yang diharapkan pelanggan belum semua sesuai dengan apa yang diperoleh pelanggan dilnstalasi Radiologi RSUD Panembahan Senopati Bantul. 
Lewis dan Booms (1983) mendefinisikan kualitas jasa sebagai ukuran seberapa bagus tingkat layanan yang diberikan mampu sesuai dengan ekspektasi pelanggan. Menurut Parasuraman,et al, (1985) ada dua faktor utama yang mempengaruhi kualitas jasa yaitu: jasa yang diharapkan (expected service) dan jasa yang dirasakan/dipersepsikan (perceived service). Apabila perceived service sesuai dengan expected service, maka kualitas jasa yang bersangkutan akan dipersepsikan baik atau positif. Jika perceived service melebihi expected service, maka kualitas jasa dipersepsikan sebagai kualitas ideal. Sebaliknya apabila perceived service lebih jelek dibandingkan expected service, maka kualitas jasa dipersepsikan negatif atau buruk.

Tjiptono dan Chandra (2011) mengemukakan bahwa Kualitas berkaitan erat dengan kepuasan pelanggan. Menurut Kotler (2000), Kualitas Jasa harus dimulai dari kebutuhan pelanggan dan berakhir dengan kepuasan pelanggan serta persepsi positif terhadap kualitas jasa. Kepuasan konsumen dapat disimpulkan sebagai suatu perasaan positif atau menyenangkan yang diperoleh seseorang terhadap jasa yang telah dibelinya setelah membandingkan harapan dengan kenyataan yang diberikan jasa tersebut. Menurut Oliver (1980), Kepuasan adalah tingkat perasaan seseorang (pelanggan) setelah membandingkan antara kinerja atau hasil yang dirasakan (pelayanaan yang diterima dan dirasakan) dengan yang diharapkannya. Kualitas memberikan dorongan khusus bagi para pelanggan untuk menjalin hubungan yang saling menguntungkan dalam waktu jangka panjang dengan perusahaan. Ikatan emosional semacam ini memungkinkan perusahaan untuk memahami dengan seksama harapan dan kebutuhan spesifik pelanggan. Atau dengan kata lain, Customer Satisfaction adalah memberikan kepada pelanggan apa yang betul-betul mereka butuhkan dan inginkan, bukan memberikan apa yang kita pikirkan dibutuhkan oleh mereka.

Dari hasil analisis perhitungan gap secara keseluruhan menunjukkan nilai gap negatif yaitu $-0,961$, berarti apa yang diharapkan pelanggan (pasien) belum sepenuhnya sesuai dengan apa yang diperoleh pelanggan (pasien) di Instalasi Radiologi Rumah Sakit Panembahan Senopati Bantul.

\section{SIMPULAN DAN SARAN \\ A. Simpulan}

Berdasarkan hasil penelitian yang dilakukan di Instalasi Radiologi Rumah Sakit Umum Daerah (RSUD) Panembahan Senopati Bantul, maka dapat disimpulkan sebagai berikut :

1) Dari hasil perhitungan defuzzyfikasi, nilai persepsi tertinggi dari kualitas pelayanan jasa Instalasi Radiologi RSUD Panembahan Senopati Bantul kepada pelanggan (pasien) adalah "Petugas mampu membuat pasien merasa aman saat diberikan pelayanan" dengan nilai 9,563. Dan nilai persepsi terendah adalah "Peralatan yang digunakan belum menggunakan teknologi terbaru (mutakhir)" dengan nilai 8,813.

2) Dari hasil defuzzyfikasi dapat diketahui nilai harapan tertinggi dari kualitas pelayanan jasa Instalasi Radiologi RSUD Panembahan Senopati Bantul kepada pelanggan adalah "Petugas mampu menumbuhkan rasa percaya 
kepada pasien" dengan nilai 10,667. Dan nilai terendah adalah "Petugas harus membuat catatan medis" dengan nilai 9,938.

3) Dari hasil perhitungan defuzzyfikasi per kriteria dan per dimensi, yang memiliki nilai servqual (gap) tertinggi adalah Tangibles (meliputi fasilitas yang tersedia belum lengkap dan memadai, alat yang digunakan belum menggunakan teknologi terbaru (mutakhir), dan ruang radiologi (ruang tunggu) yang belum nyaman) menempati ranking pertama dengan jumlah skor -1,161. Dan menjadi prioritas untuk diperbaiki dalam peningkatan kualitas pelayanan.

4) Dari hasil analisis perhitungan gap defuzzyfikasi secara keseluruhan menunjukan nilai negatif yaitu $-0,961$, berarti apa yang diharapkan pelanggan (pasien) belum sepenuhnya sesuai dengan apa yang diperoleh pelaggan (pasien) di Instalasi Radiologi Rumah Sakit Panembahan Senopati Bantul

\section{B. Saran}

Berdasarkan hasil kesimpulan tentang Analisis tingkat kualitas pelayanan jasa menggunakan metode servqual fuzzy di Instalasi Radiologi RSUD Panembahan Senopati Bantul, maka saran yang dapat disampaikan untuk meningkatkan kualitas pelayanan antara lain :

1) Menambah dan menyempurnakan fasilitas yang ada dengan memberi tanda atau petunjuk kepada pasien mengenai alur layanan berupa tulisan atau gambar agar lebih jelas, selain disediakan pengeras suara.

2) Menambah alat yang lebih modern yang berbasis komputerisasi (komputer radiografi) agar pelayanan lebih cepat dan dapat mengurangi waktu tunggu yang lama bagi pasien.

3) Memperbaiki sistem pelayanan yang ada terutama dari segi proses dengan meninjau ulang kembali SOP (Standar Operating Procedure) yang ada di Instalasi Radiologi supaya tidak dianggap rumit dan menyulitkan agar keluhan pasien mengenai lama waktu tunggu dapat teratasi.

4) Memperbaiki pengaturan tata letak (layout) ruangan agar tidak membingungkan pasien dengan memisahkan antara ruang pendaftaran atau ruang pengambilan foto agar lebih efektif dalam memberikan pelayanan

\section{DAFTAR PUSTAKA}

1. Adisasmito, Wiku. 2007. Sistem Manajemen Lingkungan Rumah Sakit. Jakarta: PT. Raja Grafindo Persada.

2. Aisyati, Azizah, dkk. 2007. Analisa Kualitas Pelayanan RSUD Wonogiri menggunakan metode Fuzzy- Servqual. Skripsi. Jurusan Teknik Industri Fakultas Teknik. Universitas Sebelas Maret. Jurnal Gama Teknik. Nomor 2/ Tahun X Juli 2007. (Diakses online puslit2.petra.ac.id/ejournal/index.php/gem/article/view file/17601/17515 pada tanggal 16 Desember 2011 jam 11:07).

3. Arikunto, dan Suharsini. 2006. Prosedur Penelitian Suatu Pendekatan Praktik. Jakarta: PT. Rineka Cipta 
4. Ariyani, Enny. 2009. Peningkatan Kualitas Pelayanan Jasa Kesehatan di Instalasi Rawat Inap Dengan Metode Servqual - Fuzzy (Studi Di Rumah Sakit Umum Daerah (RSUD) Jombang). Skripsi. Jurusan Teknik Industri Fakultas Teknik. Universitas Pembangunan Nasional V Jawa Timur. Jurnal Penelitian Ilmu Teknik Vol.9, No.1 Juni 2009. (Diakses online http://www.earthshare.org/ pada tanggal 14 Juni 2012 jam 11:45).

5. Azwar, Azrul. 2010. Program Menjaga Mutu Pelayanan Kesehatan (Aplikasi prinsip Lingkaran Pemecahan Masalah). Jakarta: Perkumpulan Kontrasepsi Mantap Indonesia (PKMI).

6. Depkes, UU no 44 tahun 2009 tentang Rumah Sakit.

7. Depkes, 1999. Rencana Pembangunan Bidang Kesehatan 2010.

8. Diana, Sari, Irene. 2009. Manajemen Pemasaran Usaha Kesehatan. Yogyakarta: Penerbit Mitra Cendekia Press.

9. Kotler, Philip. 2009. Manajemen Pemasaran edisi ketigabelas. Jakarta: Erlangga.

10. Kusumadewi, S. dan Purnomo. 2010. Aplikasi Logika Fuzzy untuk pendukung keputusan, edisi 2. Yogyakarta: Graha Ilmu.

11. Kusumadewi, S. 2010. Analisis dan Desain Sistem Fuzzy menggunakan Tool Box Matlab. Yogyakarta: Graha IImu.

12. Nurcaya.I.N, 2008. Analisis Kualitas Pelayanan Rumah Sakit di Provinsi Bali. Skripsi. Fakultas Ekonomi. Universitas Udayana Bali. (Diakses online ejournal ]http://www.digilib.udayanan.ac.id pada tanggal 16 Desember 2012 jam 11:33).

13. Notoatmodjo, Soekidjo. 2002. Metodelogi Penelitian Kesehatan. Jakarta : PT Rineka Cipta.

14. Notoatmodjo, Soekidjo. 2010. Metodelogi Penelitian Kesehatan. Jakarta : PT Rineka Cipta.

15. Permenkes Tahun 1988 No. 159b/ Menkes/ Kes/ II/ 1988 Bab II Pasal 3.

16. Profil Rumah Sakit Umum Daerah (RSUD) Panembahan Senopati Bantul 2012

17. Riwidikdo, Handoko. 2009. Statistik Kesehatan. Yogyakarta: Mitra Cendekia Press.

18. Riyanto, Agus. 2010. Pengolahan dan Analisis Data Kesehatan. Yogyakarta: Nuha Medika.

19. Riyanto, Agus. 2011. Aplikasi Metodologi Penelitian Kesehatan. Yogyakarta: Nuha Medika.

20. Rukun. 2011. Analisis Kepuasan Pasien Terhadap Mutu Pelayanan Di Instalasi Radiologi Rumah Sakit Umum Daerah Panembahan Senopati Bantul. Tugas Akhir, Politeknik Kesehatan Kemenkes Semarang.

21. Saryono. 2010. Metode Penelitian Kualitatif dalam bidang kesehatan. Yogyakarta: NuhaMedika 
22. Supranto, J. 2006. Pengukuran Tingkat Kepuasan Pelanggan untuk menaikkan pangsa pasar. Jakarta: Penerbit Rineka Cipta.

23. Sugiyono. 2007. Metode Penelitian Kuantitatif Kualitatif dan H \& D. Bandung: Penerbit Alfabeta.

24. Sugiyono. 2009. Metode Penelitian Kuantitatif Kualitatif dan $H \& D$. Bandung: Penerbit Alfabeta.

Tjiptono, Fandy dan Diana, Anastasia. 2003. Total Quality Management. Yogyakarta: Andi offset.

Tjiptono, Fandy dan Chandra, G. 2011. Service, Quality \& Satisfaction, edisi 3. Yogyakarta: Penerbit Andi.

Undang-Undang No. 23 Tahun 1992 tentang Kesehatan (diakses online, www.affavetiorg/wp-content/uploads/2010/org/UU 231992 ind.pdf pada tanggal 16 Desember 2011 jam 10:21).

Wiyono, Djoko. 2000. Manajemen Kepemimpinan dan Organisasi Kesehatan. Surabaya: Airlangga University Press.

Yamit, Zulian. 2010. Manajemen Kualitas Produk dan Jasa. Yogyakarta: Penerbit Ekonisia. 